EKONOMIKAWAN : Jurnal Ilmu Ekonomi dan Studi Pembangunan

ISSN : 1693-7600 (Print), ISSN : 2598-0157 (Online), http://jurnal.umsu.ac.Id/index.php/ekawan

\title{
Kajian Tingkat Kemiskinan di Kabupaten Batu Bara Provinsi Sumatera Utara Pasca Pemekaran
}

\author{
Lia Nazliana Nasution \\ Fakultas Sosial Sains Universitas Pembangunan Panca Budi Jl. Gatot Subroto No.km, Simpang Tj., \\ Kec. Medan Sunggal, Kota Medan, Sumatera Utara 20122 \\ e-mail : lianazliana@dosen.pancabudi.ac.id
}

\begin{abstract}
ABSTRAK
Kabupaten Batu Bara merupakan kabupaten yang lahir dari pemekaran Kabupaten Asahan pada tahun 2007. Di Kabupaten Batu Bara, jumlah penduduk miskin periode tahun 2007 sampai 2017 terus mengalami fluktuasi. Menunjukkan tren menurun mulai tahun 2007 sampai dengan tahun 2012 tetapi terus berfluktuasi mulai tahun 2013 sampai dengan tahun 2017. Penelitian ini dimaksudkan untuk mengkaji tingkat kemiskinan di kabupaten Batu Bara pasca pemekaran. Variabel yang digunakan dalam penelitian ini adalah tingkat pengangguran terbuka, TPT (X1), perumbuhan ekonomi (X2), tingkat pendidikan (X3), dan tingkat kemiskinan (Y). Data yang digunakan mulai tahun 2007 sampai dengan 2017, dengan analisis data kuantitatif metode regresi berganda. Dari hasil penelitian ditunjukkan bahwa tingkat pengangangguran terbuka (TPT), pertumbuhan ekonomi, dan tingkat pendidikan tidak mempengaruhi signifikan terhadap kemiskinan di kabupaten Batu Bara pasca pemekaran.
\end{abstract}

Kata kunci: Tingkat kemiskinan, TPT, Pertumbuhan ekonomi, dan Pendidikan. 


\title{
Poverty Rate Study in Batu Bara Regency North Sumatra Province After Division
}

\begin{abstract}
Batu Bara Regency is a Regency that was born from the division of Asahan Regency in 2007. In Batu Bara Regency, the number of poor people from 2007 to 2017 continues to fluctuate. Shows a downward trend from 2007 to 2012 but continues to fluctuate from 2013 to 2017. This research is intended to assess the level of poverty in the Batu Bara District after the expansion. The variables used in this study are open unemployment, TPT (X1), economic growth (X2), education level (X3), and poverty level (Y). Data used from 2007 to 2017, with quantitative data analysis multiple linear regression methods. From results showed that TPT, economic growth, and education level did not significantly influence the level of poverty in Batu Bara District after the expansion.
\end{abstract}

Keywords : Poverty level, TPT, economic growth, and education.

\section{PENDAHULUAN}

Kemiskinan selalu menjadi masalah di dalam perekonomian. Kemiskinan dapat menyebabkan rendahnya taraf hidup penduduk sehingga kebutuhan yang harus dipenuhi setiap hari menjadi terbatas. Tidak sedikit penduduk hidup dibawah garis kemiskinan, dan tidak sedikit pula penduduk hidup dibawah pendapatan yang rendah. Banyak programprogram bantuan pemerintah yang telah dilakukan untuk mengurangi angka kemiskinan, tetapi kurang tepatnya bantuan yang diberikan sehingga menjadi penghalang dalam mengurangi angka kemiskinan. Banyak sekali penyebab yang dapat menimbulkan kemiskinan, seperti kondisi geografis yang mempengaruhinya, faktor kultural masyarakat setempat dan berbagai masalah lainnya. Di sisi lain timbulnya kemiskinan sebagai akibat pertambahan jumlah penduduk sehingga menimbulkan penduduk miskin baru.

Kabupaten Batu Bara adalah kabupaten yang terdapat di pesisir provinsi Sumatera Utara yang resmi dibentuk berdasarkan UU No. 5 Tahun 2007 pada tanggal 25 Juni 2007. Lahir dari pemekaran kabupaten Asahan, kabupaten Batu Bara terdiri dari 7 kecamatan. Kecamatan Lima Puluh merupakan ibukota kabupaten Batu Bara. Tahun 2017 jumlah penduduk kabupaten Batu Bara berdasarkan proyeksi sebanyak 409.091 jiwa. Apabila kita membandingkan dengan proyeksi jumlah penduduk tahun 2010, Batu Bara mengalami pertumbuhan penduduk sebesar 1,19 persen. Sementara itu, jumlah penduduk miskin di kabupaten Batu Bara mengalami perubahan dari tahun 2007 sampai dengan 2017 (batubarakab.bps.go.id). Setiap tahun terjadi fluktuasi penduduk miskin baik secara absolut maupun persentase. Perkembangan jumlah penduduk miskin di kabupaten Batu Bara periode 2007 - 2017 ditunjukkan pada tabel di bawah ini. 
Published July 2019

EKONOMIKAWAN : Jurnal Ilmu Ekonomi dan Studi Pembangunan

ISSN : $1693-7600$ (Print), ISSN : 2598-0157 (Online), http://jurnal.umsu.ac.ld/index.php/ekawan

Tabel 1. Jumlah Penduduk Miskin di Kabupaten Batu Bara, 2007 - 2017

\begin{tabular}{|c|c|c|}
\hline Tahun & Penduduk Miskin (000 Jiwa) & Persentase (\%) \\
\hline 2007 & 67,70 & 17,89 \\
\hline 2008 & 51,67 & 13,64 \\
\hline 2009 & 49,50 & 12,87 \\
\hline 2010 & 46,00 & 12,29 \\
\hline 2011 & 44,34 & 11,67 \\
\hline 2012 & 43,66 & 11,24 \\
\hline 2013 & 46,86 & 11,92 \\
\hline 2014 & 44,72 & 11,25 \\
\hline 2015 & 50,37 & 12,61 \\
\hline 2016 & 49,42 & 12,24 \\
\hline 2017 & 50,91 & 12,48 \\
\hline
\end{tabular}

Sumber: BPS Kabupaten Batu Bara

Fenomena masalahnya adalah adanya fluktuasi yang terjadi di kabupaten Batu Bara baik dari aspek kemiskinan, pendidikan, pengangguran, dan pertumbuhan ekonomi dari tahun 2007 hingga tahun 2017 pasca pemekaran. Dari tabel 1 terlihat bahwa jumlah penduduk miskin di kabupaten Batu Bara meningkat mulai tahun 2014 hingga 2017. Ini berarti masih banyak masyarakat yang belum dapat memenuhi kebutuhan hidupnya diakibatkan rendahnya pendapatan.

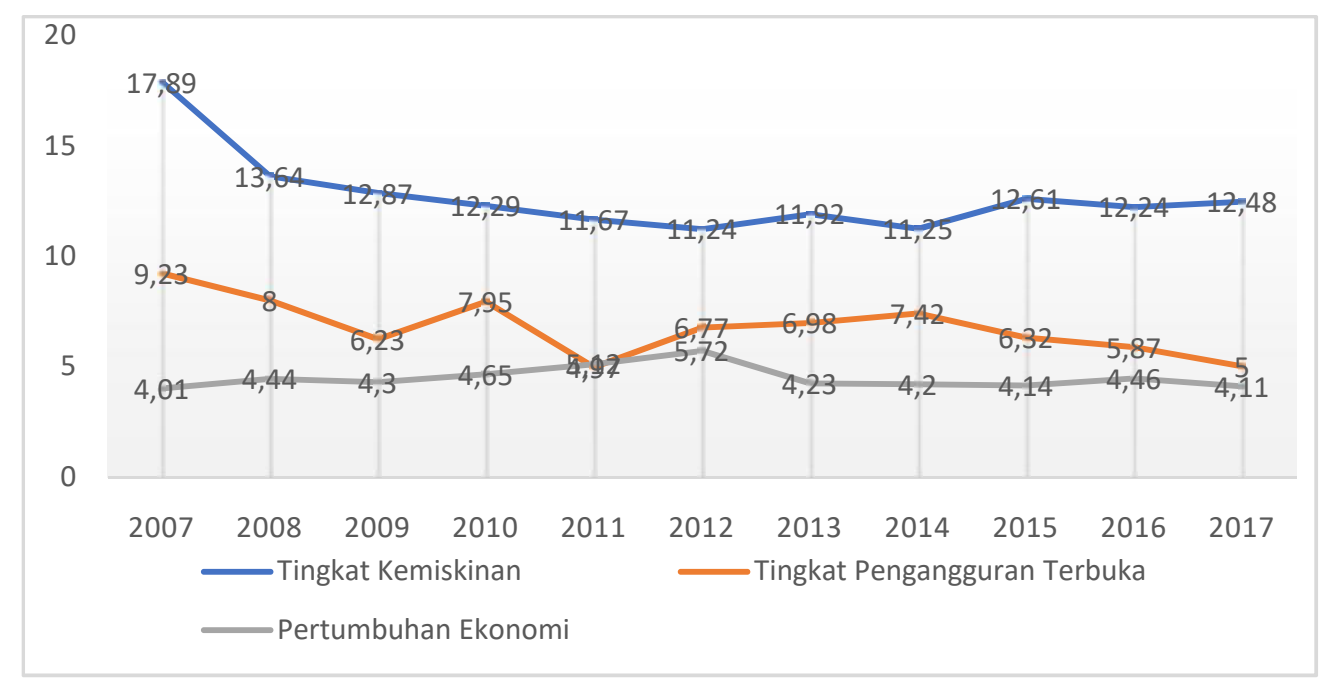

Sumber : batubarakab.bps.go.id

Gambar 1. Tren Tingkat Kemiskinan, TPT, dan Pertumbuhan Ekonomi Kabupaten Batu Bara

Berdasarkan pemaparan diatas, maka penting dilakukan penelitian untuk mengkaji apakah variabel-variabel yang diteliti berpengaruh atau tidak terhadap tingkat kemiskinan di Kabupaten Batu Bara pasca pemekaran. Hasil penelitian diharapkan dapat menjadi gambaran keadaan sebenarnya, manakah faktor yang sebenarnya berpengaruh kepada tingkat kemiskinan di kabupaten Batu Bara. 


\section{Published July 2019}

\section{EKONOMIKAWAN : Jurnal Ilmu Ekonomi dan Studi Pembangunan}

ISSN : $1693-7600$ (Print), ISSN : 2598-0157 (Online), http://jurnal.umsu.ac.ld/index.php/ekawan

\section{KAJIAN TEORI}

Kemiskinan oleh Badan Pusat Statistik diartikan sebagai ketidakmampuan dari sisi ekonomi dalam memenuhi kebutuhan dasar manusia yang pengukurannya dari sisi pengeluaran (bps.go.id). Dari beberapa penelitian terdahulu, kemiskinan dapat disebabkan oleh banyak faktor. Penelitian yang dilakukan di kabupaten Jayapura oleh Siburian (2015) menyatakan bahwa pertumbuhan ekonomi tidak memiliki pengaruh terhadap kemiskinan di kabupaten Jayapura, tetapi TPT berpengaruh positif dan signifikan terhadap kemiskinan di Kabupaten Jayapura. Sinaga (2013) menemukan bahwa kemiskinan di Kabupaten/Kota Provinsi Sumatera Utara secara positif dan signifikan dipengaruhi oleh PDRB dan penduduk tamat universitas, dan kemiskinan dalam tingkat pengangguran terbuka dipengaruhi secara negatif dan signifikan oleh penduduk tamat SD, SLTP, dan SLTA.

Di kabupaten Sumbawa, penelitian yang dilakukan tahun 2010 - 2015 (Suprianto, 2017) menyatakan bahwa tingkat kemiskinan dipengaruhi secara signifikan oleh jumlah penduduk, tingkat pendidikan, dan kesehatan. Sama halnya dengan penelitian yang dilakukan di kabupaten Buleleng (Wiradyatmika, 2013), bahwa jumlah penduduk dan penyerapan tenaga kerja berpengaruh kepada penduduk miskin secara signifikan.

Penyebab kemiskinan berawal pada teori lingkaran setan kemiskinan oleh seorang ahli ekonomi bernama Nurkse. Adanya ketertinggalan, keterbelakangan serta modal yang kurang mengakibatkan produktivitas yang rendah yang menyebabkan rendahnya pendapatan. Apabila pendapatan rendah maka tabungan dan investasi juga akan rendah. Selanjutnya pembentukan modal pun berkurang, begitu seterusnya.

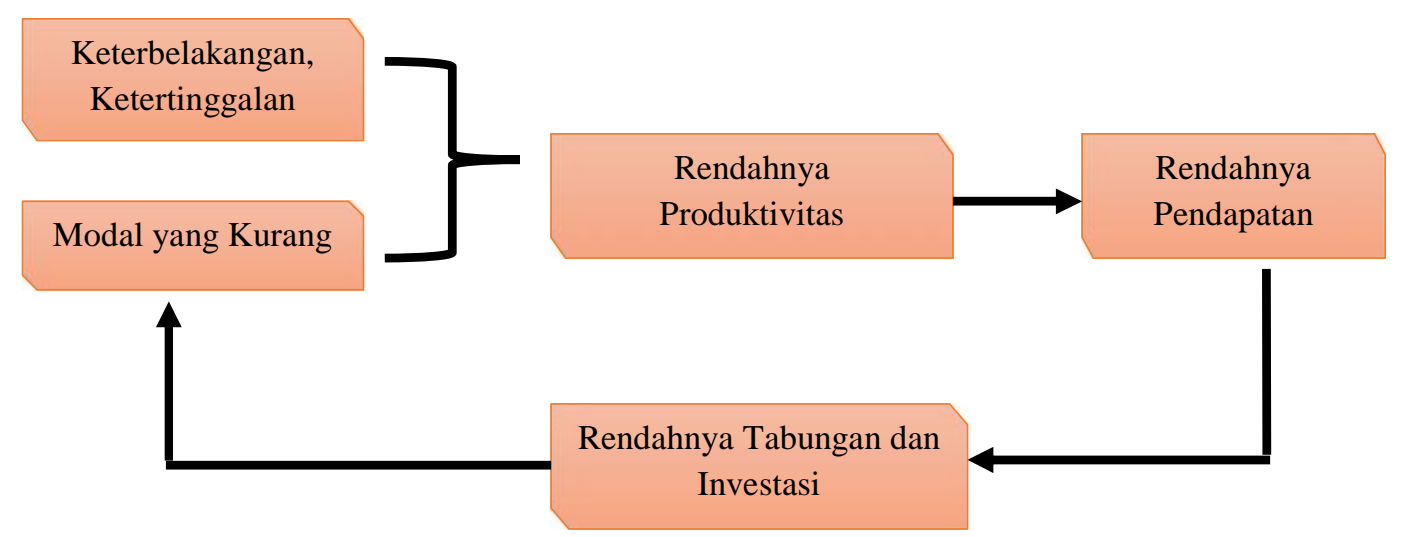

Gambar 2. Lingkaran Setan Kemiskinan

Teori lingkaran setan kemiskinan pada hakikatnya menjelaskan bahwa : (a) adanya ketidakmampuan dalam menabung, (b) kurangnya rangsangan untuk melakukan investasi, dan (c) masih tertinggal dan terbelakangnya masyarakat, yang akhirnya menjadi faktorfaktor yang menghambat terbentuknya modal dan akhirnya menghambat perekonomian suatu negara.

\section{METODE}

Penelitian ini memfokuskan pada kajian tingkat kemiskinan di kabupaten Batu Bara pasca pemekaran yang dilihat dari aspek TPT, pertumbuhan ekonomi dan tingkat pendidikan, periode tahun 2007 sampai 2017. 
Penelitian ini menggunakan pendekatan asosiatif kuantitatif. Metode analisis regresi linier berganda (multiple regression analysis) digunakan untuk menguji penelitian ini. Adapun kerangka konsep ditunjukkan pada gambar berikut :

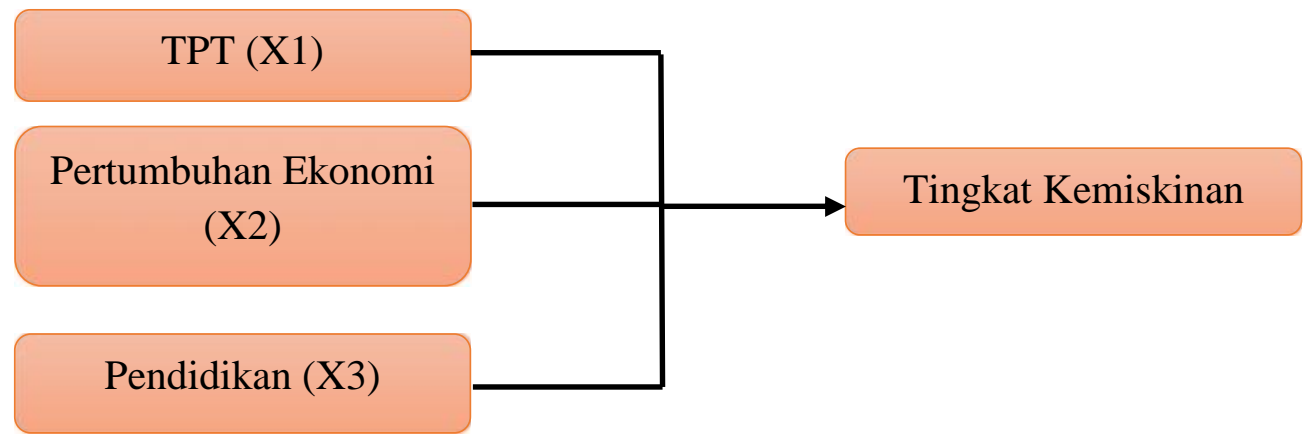

Gambar 3. Kerangka Konsep Penelitian

\section{HASIL DAN PEMBAHASAN}

Dari hasil pengolahan dengan menggunakan SPSS, maka persamaan regresinya adalah sebagai berikut :

Tkt Kemiskinan $=29,857+$ 0,29 TPT $-1,795$ Pertumbuhan $-0,167$ Pendidikan $+\mathrm{e}$

Tabel 2. Nilai Koefisien Variabel

\begin{tabular}{|l|c|c|}
\hline \multicolumn{1}{|c|}{ Variabel } & Koefisien & $\mathrm{t}-\mathrm{sig}$ \\
\hline $\mathrm{C}$ & 29,857 & 0,012 \\
\hline TPT (X1) & 0,290 & 0,462 \\
\hline Pertumbuhan Ekonomi (X2) & $-1,795$ & 0,063 \\
\hline Tingkat Pendidikan (X3) & $-0,167$ & 0,065 \\
\hline F-Sig & 0,031 \\
\hline $\mathrm{R}^{2}$ & 0,697 \\
\hline
\end{tabular}

\section{Pengujian Test Goodness of Fit}

\section{Interpretasi Koefisien Determinasi (R-square)}

Nilai R-square 0,697 artinya bahwa variasi dari TPT, Pertumbuhan ekonomi, dan tingkat pendidikan dapat menjelaskan tingkat kemiskinan sebesar 69,7\% sedangkan 30,3\% sisanya variasi dari tingkat kemiskinan dijelaskan oleh variabel lain yang tidak disertakan ke dalam model.

\section{Interpretasi Uji t}

a) Nilai koefisien variabel TPT sebesar 0,290 dengan signifikansi sebesar 0,462 > 0,05. Artinya variabel TPT memberikan pengaruh positif yang tidak signifikan terhadap tingkat kemiskinan di Kabupaten Batu Bara pada tingkat kepercayaan 95\% selama kurun waktu 2007 - 2017.

b) Nilai koefisien pertumbuhan ekonomi sebesar -1,795 dengan signifikan 0,063>0,05. Artinya variabel tingkat kemiskinan dipengaruhi oleh pertumbuhan ekonomi secara negatif dan tidak signifikan di kabupaten Batu Bara pada tingkat kepercayaan 95\% selama kurun waktu 2007 - 2017. 
Published July 2019

EKONOMIKAWAN : Jurnal Ilmu Ekonomi dan Studi Pembangunan

ISSN : $1693-7600$ (Print), ISSN : 2598-0157 (Online), http://jurnal.umsu.ac.Id/index.php/ekawan

c) Nilai koefisien variabel tingkat pendidikan sebesar -0,167 dan signifikan 0,065 > 0,05. Mengartikan bahwa variabel tingkat kemiskinan dipengaruhi oleh tingkat pendidikan secara negatif dan tidak signifikan di kabupaten Batu Bara pada tingkat kepercayaan 95\% selama kurun waktu 2007 - 2017.

\section{Interpretasi Uji F}

Nilai probability $\mathrm{F}$ statistik sebesar $0,031<0,05$, maka terdapat pengaruh yang signifikan secara simultan. Artinya variabel TPT, pertumbuhan ekonomi, dan tingkat pendidikan secara bersama berpengaruh signifikan terhadap tingkat kemiskinan pada tingkat kepercayaan $95 \%$.

\section{Uji Asumsi Klasik}

\section{Uji Autokorelasi}

Berdasarkan hasil LM test menunjukkan nilai Prob Chi square (2) 0,8640>0,05 yang artinya tidak ada masalah autokorelasi antar faktor pengganggu (error term).

Tabel 3. LM Test

\begin{tabular}{|c|l|l|l|}
\hline LM Test & 0.068255 & Prob. F(2,5) & 0.9349 \\
\hline F-statistic & 0.292342 & Prob. Chi-Square(2) & 0.8640 \\
\hline Obs*R-squared & 0.068255 & Prob. F(2,5) & 0.9349 \\
\hline
\end{tabular}

\section{Uji Multikolinearitas}

Nilai VIF untuk variabel TPT, pertumbuhan ekonomi, dan tingkat pendidikan masing-masing sebesar 1,604, 1,174, dan 1,562. Nilai tersebut kurang dari 10, artinya tidak ada masalah multikolinearitas.

Tabel 4. Nilai Tolerance dan VIF

\begin{tabular}{|l|c|c|}
\hline \multicolumn{1}{|c|}{ Variabel } & Tolerance & VIF \\
\hline C & & \\
\hline TPT (X1) & 0,623 & 1,604 \\
\hline Pertumbuhan Ekonomi (X2) & 0,852 & 1,174 \\
\hline Tingkat Pendidikan (X3) & 0,640 & 1,562 \\
\hline
\end{tabular}

\section{Uji Heterokedastisitas}

Untuk uji heterokedastisitas digunakan uji Breusch Pagan Godfrey. Dari hasil di atas nilai Prob. Chi quare (3) pada Obs*R-square yaitu sebesar 0,1869>0,05 artinya model regresi tidak ada masalah heterokedastisitas.

Tabel 5. Uji Breusch Pagan Godfrey

\begin{tabular}{|l|l|l|r|}
\hline F-statistic & 1.807789 & Prob. F(3,7) & 0.2334 \\
\hline Obs*R-squared & 4.802002 & Prob. Chi-Square(3) & 0.1869 \\
\hline Scaled explained SS & 1.038922 & Prob. Chi-Square(3) & 0.7918 \\
\hline F-statistic & 1.807789 & Prob. F(3,7) & 0.2334 \\
\hline
\end{tabular}


Published July 2019

EKONOMIKAWAN : Jurnal Ilmu Ekonomi dan Studi Pembangunan

ISSN : 1693-7600 (Print), ISSN : 2598-0157 (Online), http://jurnal.umsu.ac.Id/index.php/ekawan

\section{Pembahasan}

1. Dari hasil pengujian, TPT memiliki pengaruh positif namun tidak signifikan terhadap tingkat kemiskinan di kabupaten Batu Bara. Nilai positif sesuai dengan teori bahwa jika pengangguran meningkat akan menyebabkan tingkat kemiskinan juga meningkat. Namun di kabupaten Batu Bara ini, ternyata TPT tidak berpengaruh terhadap tingkat kemiskinan. Berbeda dengan penelitian Waruwu (2016) bahwa ada pengaruh yang signifikan antara pengangguran dan tingkat kemiskinan. Pada penelitian ini, tidak adamya pengaruh antara TPT dan tingkat kemiskinan dapat disebabkan karena masyarakat yang memiliki pendapatan alias bekerja tetap tidak bisa mencukupi kebutuhannya mungkin dikarenakan tingkat pendapatan yang rendah sehingga kemiskinan tidak teratasi.

2. Dari hasil pengujian menunjukkan bahwa tingkat kemiskinan di kabupaten Batu Bara dipengaruhi secara negatif tidak signifikan oleh pertumbuhan ekonomi. Nilai negatif sesuai dengan teori, apabila pertumbuhan ekonomi naik maka kemiskinan turun. Namun di kabupaten Batu Bara ini, ternyata pertumbuhan ekonomi tidak memiliki pengaruh terhadap tingkat kemiskinan. Hal ini disebabkan karena pertumbuhan ekonomi di kabupaten Batu Bara peningkatan setiap tahunnya tidak terlalu tinggi. Kurang digalinya potensi sumber daya yang ada di kabupaten Batu Bara dapat menyebabkan tingkat pertumbuhan ekonomi juga masih rendah sehingga tidak dapat mengurangi angka kemiskinan. Berbeda dengan penelitian yang dilakukan Hambarsari dan Inggit (2016), dan Kuncoro (2014).

3. Dari hasil pengujian, tingkat kemiskinan di kabupaten Batu Bara dipengaruhi oleh pendidikan secara negatif dan tidak signifikan. Nilai negatif sesuai dengan teori bahwa jika tingkat pendidikan naik maka tingkat kemiskinan akan turun. Namun di kabupaten Batu Bara ini, ternyata tingkat kemiskinan tidak dipengaruhi oleh tingkat pendidikan. Hal ini berbeda dengan penelitian yang dilakukan oleh Suprianto (2017), bahwa tingkat kemiskinan tidak dipengaruhi secara signifikan oleh tingkat pendidikan. Pada penelitian ini, tidak adamya pengaruh antara tingkat pendidikan dan tingkat kemiskinan dapat disebabkan karena masyarakat kabupaten Batu Bara tingkat pendidikan tertinggi cenderung tamatan SMP ataupun SMA, sedangkan yang tamatan sarjana masih tergolong sedikit.

\section{SIMPULAN}

Tingkat kemiskinan di kabupaten Batu Bara pasca pemekaran tidak dipengaruhi secara signifikan oleh variabel TPT, sama seperti penelitian yang dilakukan oleh Sinaga (2013). Selain itu, tingkat kemiskinan juga tidak dipengaruhi secara signifikan oleh pertumbuhan ekonomi dan tingkat pendidikan, sejalan dengan penelitian oleh Siburian (2015) bahwa pertumbuhan ekonomi tidak mempengaruhi terhadap tingkat kemiskinan di Kabupaten Jayapura, namun berbeda dengan penelitian yang dilakukan oleh Sinaga (2013) bahwa kemiskinan dipengaruhi secara signifikan oleh pendidikan. 
EKONOMIKAWAN : Jurnal Ilmu Ekonomi dan Studi Pembangunan

ISSN : $1693-7600$ (Print), ISSN : 2598-0157 (Online), http://jurnal.umsu.ac.ld/index.php/ekawan

\section{DAFTAR PUSTAKA}

batubarakab.bps.go.id

bps.go.id

Siburian, Evi Hartati. 2015. Analisis Pengaruh Pertumbuhan Ekonomi dan Pengangguran Terhadap Tingkat Kemiskinan di Kabupaten Jayapura. Jurnal Kajian Ekonomi dan Studi Pembangunan. Vol. 2, No. 11. Jurusan Ilmu Ekonomi Fakultas Ekonomi dan Bisnis. Universitas Cenderawasih.

Sinaga, Pestaria, K. 2013. Analisis Pengaruh Produk Domestik Regional Bruto, Pendidikan dan Pengangguran Terhadap Kemiskinan di Kab/Kota Propinsi Sumatera Utara Tahun 2010-2011. Saintia Matematika Vo. 1, No. 3.

Sukirno, Sadono. 2011. Ekonomi Pembangunan : Proses, Masalah, dan Dasar Kebijakan. Edisi Kedua, Kencana Prenada Media Group. Jakarta.

Suprianto. 2017. Analisis Pengaruh Jumlah Penduduk, Tingkat Pendidikan, dan Kesehatan

Terhadap Tingkat Kemisikinan di Kabupaten Sumbawa Tahun 2010-2015.

Fakultas Ekonomi \& Manajemen. Universitas Samawa. Jurnal Ekonomi dan Bisnis Vol 14 No 2.

Undang-Undang Republik Indonesia Nomor 5 Tahun 2007.

Wiradyatmika, A.A Gde Alit. 2013. Pengaruh Jumlah Penduduk, Jumlah Penyerapan Tenaga Kerja dan Pengangguran Terhadap Jumlah Penduduk Miskin di Kabupaten Buleleng. Jurusan Ekonomi Pembangunan Fakultas Ekonomi. Universitas Udayana. E-Jurnal Ekonomi Pembangunan. Universitas Udayana Vol. 2, No. 7. 